\title{
Tyrosine-Protein Kinase CSK
}

National Cancer Institute

\section{Source}

National Cancer Institute. Tyrosine-Protein Kinase CSK. NCI Thesaurus. Code C17528.

Tyrosine-protein kinase CSK (450 aa, $\sim 51 \mathrm{kDa}$ ) is encoded by the human CSK gene. This protein plays a role in tyrosine phosphorylation, signal transduction and T-cell activation. 